American Journal of Applied Sciences 9 (8): 1194-1198, 2012

ISSN 1546-9239

(C) 2012 Science Publications

\title{
Study of Ambient and Indoor Air Quality in the Building Built on the Former Landfill
}

\author{
Anuar Ithnin, Nazipah Zakaria, Nor Azura Sulong, \\ Shamrul Aizam Abd. Rahman, Normah Awang and Nurul Farahana Kamaludin \\ Environmental Health and Industrial Safety Program, \\ Faculty of Health Sciences, Universiti Kebangsaan Malaysia, \\ Jalan Raja Muda Abdul Aziz, 50300, Kuala Lumpur, Malaysia
}

\begin{abstract}
Problem statement: The air quality study of PPR Taman Wahyu II, Selayang, Selangor was a residential project that was built on the former landfill site. The landfill site will produce landfill gases which can influence the air quality level in and outside the building. Approach: This air quality study also involving PPR Intan Baiduri, Batu Caves, Selangor as a control building. The air quality parameters chosen were physical, chemical and biological. Instruments used were HVS, Biogas Analyzer, Aeroqual, MultiRAE, ICP-MS, NMAM 7303 and gravimetric method. Gilian High Volume Air Sampler was used to measure heavy metal parameters that were conducted for $8 \mathrm{~h}$, Personal Sampling Pump to measure total suspended particulates for $8 \mathrm{~h}$, MultiRAE for $\mathrm{H}_{2} \mathrm{~S}$ and $\mathrm{CH}_{4}$ gas, Aeroqual for $\mathrm{CO}_{2}$ gas, Multilog for $\mathrm{CO}$ gas and a Tedlar bag for $\mathrm{O}_{2}$ gas. For biological parameters, settle plate method was used and conducted for $20 \mathrm{~min}$. Veloci CALC and wind probe were used to measure physical parameters. Results: In the ambient air, the mean concentration of Total Suspended Particulate (TSP), lead and cadmium were higher at an exposed location compared to the control with a reading of $0.325 \pm 0.29,0.108 \pm 0.050$ and $0.06 \pm 0.045 \mathrm{ng} \mathrm{m}^{-3}$ respectively. The reason was that the exposed location was a former landfill site and there were several co-founding factors. Mean concentration for chemical parameters were higher at the exposed location and all the chemical parameters were not exceeding the EPA Protocol Gas for Single Component. The mean concentration of oxygen is $20.95 \pm 0.005 \%$, carbon dioxide $669.25 \pm 84.109 \mathrm{ppm}$ and carbon monoxide $1.8 \pm 0.957 \mathrm{ppm}$. For biological parameters, mean for the colony total count also higher at the exposed location compared to control location where the mean for bacterial was $17.75 \pm 4.573 \mathrm{cfu}$ while for fungal, the mean is $8.0 \pm 2.828$ cfu. Indoor air quality results showed that concentration means of $\mathrm{CO}_{2}$ was $877.8 \pm 59.40 \mathrm{ppm}, \mathrm{CO}$ was $5.0 \pm 0.89 \mathrm{ppm}$ and $\mathrm{O}_{2}$ was $20.9 \pm 0.05 \%$. The concentration means for $\mathrm{Cd}$ was $0.3 \pm 0.26 \mathrm{ng} \mathrm{m}^{-3}, \mathrm{~Pb}$ was $0.5 \pm 0.21 \mathrm{ng} \mathrm{m}^{-3}$, TSP was $0.2 \pm 0.08 \mathrm{mg} \mathrm{m}^{-3}$, bacteria was $38 \pm 16 \mathrm{cfu}$ and fungal was $11 \pm 7 \mathrm{cfu}$. Conclusion: The concentration mean of the gas parameters had fulfilled the guideline standard. The statistical analysis revealed that there were significant differences between $\mathrm{CO}_{2}, \mathrm{O}_{2}$, bacterial, fungal and TSP between research building and control building. Research also showed that there is no differentiation between former landfill ambient air and control ambient air quality.
\end{abstract}

Key words: Landfill site, total suspended particulate, colony total count

\section{INTRODUCTION}

Disposal site is the physical facility for removal or disposal of solid waste or rubbish in soil PPSPA 2009. In Malaysia, there are almost 230 landfill sites which are still in operation, active and most of them are open landfills (Samsudin et al., 2006). The landfill will naturally produce landfill gases as a by-product through the process of decaying organic matter. Most of the landfill gases composed of carbon dioxide and methane.
Both of them are greenhouse gases which will lead to global warming (ATSDR, 2001). Landfill gases will enter the building via the foundation cracks and gaps, pressure differences between the inside and outside the building or home, mechanical ventilation systems and leakage areas (e.g., utility entry points, construction joints, or floor drain systems). All these shall become as entry points for the gases. Buildings and houses with basements generally provide the most access for gases in the soil to migrate. Many factors

Corresponding Author: Anuar Ithnin, Environmental Health and Industrial Safety Programme, Faculty of Health Sciences, Universiti Kebangsaan Malaysia, Jalan Raja Muda Abdul Aziz, 50300, Kuala Lumpur, Malaysia 
that contribute to the amount of gases that migrate into the building including the construction and maintenance practices (ATSDR, 2001).

Landfill gases and leachate production can give effect to the soil, underground water and to the surrounding air or nearby even though it has been closed for several years (Schrapp and Al-Mutairi, 2010). Dust in the air usually contains total suspended particles and several heavy metals especially lead, cadmium and mercury. These heavy metals can cause health effects to human (Jarup, 2003). Total suspended particles are a mixture of small solid particles and droplets in air which usually produced from power plants, industrials, transport and others (Fierro, 2000). Chemical hazards are landfill gases which include methane, hydrogen sulfide, carbon dioxide and carbon monoxide. All of these gases are produced from the degradation process of organic material by the bacteria in the soil. There are four phases of the degradation process which are aerobic, anaerobic, organic acid usage by anaerobic bacteria and the stable phase of landfill gas production. During all these phases, the compositions of gases produced are always changed. These gases then migrate through soil pores, cracks and escapes into the air (ATSDR, 2001).

The purpose of this study is to determine the status of ambient and indoor air quality in the residential area built on the former landfill site, PPR Taman Wahyu II which comprised of gas, heavy metal, total suspended particulates and microbe parameters. Gas parameters are the most important components of this study to evaluate the emission level of gases at this former landfill site and their effects towards the air quality. The study related to air quality of the building that was built on the former landfill sites are still less compared than other countries.

\section{MATERIALS AND METHODS}

\section{Sampling locations:}

PPR Taman Wahyu II, Selayang: PPR Taman Wahyu II, which is located in Selayang, Selangor (N3.22074 E101.67005 ${ }^{\circ}$ ) is a residential housing built at the former landfill site. This location was a landfill site but had been redeveloped to a housing resident after its closure for about more than ten years ago. However, the housing resident was built a few years ago and started its operation in the year 2002. All of the units were only filled in the year 2004. It is a public housing with a variety of residential races which are Malays, Chinese and Indians. Therefore, this location is the most suitable place to conduct an air quality study of the building that was built on the former landfill site.

PPR Intan Baiduri, Batu caves: PPR Intan Baiduri, which is located in Batu Caves, Selangor (N3. 23406
E101. $65425^{\circ}$ ), is also a residential housing as the PPR Taman Wahyu II. However, it is not built on a former landfill site but on a normal ground and this location is the most appropriate place to be used as control location for the study. This control location is almost the same as the study location in terms of its facilities, buildings and resident races. PPR Intan Baiduri is situated $11.5 \mathrm{~km}$ from the study location, PPR Taman Wahyu II.

Research parameter: The chosen parameters were physical, chemical and biological. The physical parameters include temperature, relative humidity, air velocity and total suspended particulates. The chemical parameters involve gases like methane, hydrogen sulfide, carbon dioxide, carbon monoxide, oxygen and heavy metals like lead and cadmium. The biological parameters include total bacterial and fungal count.

Physical parameters: Temperature and relative humidity parameters were measured by using Veloci CALC that was obtained from the Environmental Health Laboratory. This instrument is a direct reading measurement and was recorded for 3 times to obtain the accurate result. The measurement of air velocity was done by using Veloci CALC with wind probe attached to it. The reading was also taken in 3 times to obtain an accurate result. The measurement of total suspended particulates is done by using personal high volume air sampler. This instrument is equipped with filter paper and cellulose membrane acetate $0.8 \mathrm{um}$. The dust will trap into it. The measurement was done for $8 \mathrm{~h}$ period. The total suspended particulates were measured by making a comparison between the original weight of the filter paper and the final weight of the filter paper after sampling. The filter paper was weighed using an electronic scale.

Chemical parameters: Methane and hydrogen sulfide gases were measured by using direct reading instrument, MultiRAE for $30 \mathrm{~min}$. Carbon dioxide was measured using by Aeroqual while carbon monoxide was measured using by Multilog and the reading was taken for 3 times to obtain the accurate result. Oxygen gas was measured using by Personal High Volume Air Sampler which attached to the Tedlar bag. The air was drawn into the Tedlar bag using the pump. It was then being analyzed using biogas analyzer. The heavy metal parameters were measured using Gillian High Volume Sampler that was equipped with filter paper, membrane cellulose acetate $0.8 \mathrm{um}$ for $8 \mathrm{~h}$ period. The dust containing heavy metals would trap into the filter paper. The filter paper was then analyzed in the lab where the acid digestion method (NIOSH, 2003) was carried out. The filter paper was cut into small pieces and placed 
Am. J. Applied Sci., 9 (8): 1194-1198, 2012

into the conical flask. $1.25 \mathrm{~mL} \mathrm{HCL}(70 \%)$ was poured into the flask and heated using hot plate at $95^{\circ} \mathrm{C}$ for 15 min. Then, the flask was lifted and cooled for 5 min. Later, $1.25 \mathrm{~mL} \mathrm{HNO}_{3}(70 \%)$ was poured into the flask and heated using the hot plate at $95^{\circ} \mathrm{C}$ for 15 min. After that brown fumes are produced, the conical flask was lifted and cooled for $5 \mathrm{~min}$. The liquid obtained is added to deionized water until the final solution of $25 \mathrm{~mL}$ was obtained. The final volume was then filtered using membrane cellulose acetate filter paper $0.2 \mathrm{um}$. Then, the obtained sample was analyzed using ICP-MS method.

Biological parameters: The biological parameters, total bacterial and total fungal count were measured by using settle plate method. The petri dish containing Tripical Soy Agar (TSA) was exposed to the air for 10 min and the petri dish containing Sabouraud Dextrose Agar (SDA) was also exposed to the air for $10 \mathrm{~min}$. After the sampling was over, the petri dish was incubated in the incubator for 1 day (TSA) and 3 days (SDA). The total colonies form in the petri dish was counted using Colony Counter Galaxy 230.

\section{RESULTS}

Based on the Independent T-test that was conducted, results of outdoor air quality (Table 1) showed that all physical parameters except for the TSP was slightly higher than the study location as compared to the results at the control location. However TSP concentration in air at both locations showed the same reading which is $0.325 \pm 0.000 \mathrm{mg} \mathrm{m}^{-3}$.

Results from the statistical analysis also showed that there are two significant differences between the study and control location for the physical parameters which the temperature with $\mathrm{p}$ value $0.027(\mathrm{p}<0.05)$ and relative humidity with $\mathrm{p}$ value $0.000(\mathrm{p}<0.05)$. Other parameters only show a slight difference in the concentration readings and considered as not too significant.

The chemical parameters of outdoor air (Table 2) which were the landfill gases showed there was no significant difference $(p>0.05)$ between the concentration of study and control location. The concentration of methane and hydrogen sulfide are 0 ppm at both locations.

For biological study, results showed (Table 3) that there was a significant difference $(p<0.05)$ between total colony counts at studied and control location for bacteria. For the fungal parameter, there was no significant difference $(\mathrm{p}>0.05)$ in the total colony count. The mean concentration for all indoor air quality parameters was simplified in Table 4.
Table 1: Physical parameters mean readings about outdoor air quality

\begin{tabular}{llllllll}
\hline Location & Zone & $\begin{array}{c}\text { Temp. } \\
\left({ }^{\circ} \mathrm{C}\right)\end{array}$ & $\begin{array}{l}\mathrm{RH} \\
(\%)\end{array}$ & $\begin{array}{l}\text { Wind } \\
\text { Speed }(\mathrm{m} / \mathrm{sec})\end{array}$ & $\begin{array}{l}\text { TSP } \\
\left(\mathrm{mg} / \mathrm{m}^{3}\right)\end{array}$ & $\begin{array}{l}\mathrm{Pb} \\
\left(\mathrm{ng} / \mathrm{m}^{3}\right)\end{array}$ & $\begin{array}{l}\mathrm{Cd} \\
\left(\mathrm{ng} / \mathrm{m}^{3}\right)\end{array}$ \\
\hline PPR & A & 31.95 & 79 & 0.1 & 0.4 & 0.04 & n.d* \\
Taman & B & 32.85 & 82 & 0.2 & 0.1 & 0.16 & 0.06 \\
Wahyu & C & 31.67 & 84 & 0.2 & 0.7 & 0.12 & 0.09 \\
& Field & 31.16 & 84 & 0.2 & 0.1 & 0.11 & 0.1 \\
PPR & A & 30.70 & 72 & 0.2 & 0.6 & n.d* & n.d* \\
Intan & B & 31.30 & 71 & 0.3 & 0.2 & n.d* & n.d* \\
Baiduri & C & 29.60 & 74 & 0.1 & 0.1 & n.d* & n.d* \\
& Field & 30.00 & 72 & 0.1 & 0.4 & n.d* & n.d* \\
\hline
\end{tabular}

*: n.d - not determined

Table 2: Concentration of gas in indoor air

\begin{tabular}{lllll}
\hline Location & Zone & $\begin{array}{l}\mathrm{O}_{2} \\
(\%)\end{array}$ & $\begin{array}{l}\mathrm{CO}_{2} \\
(\mathrm{ppm})\end{array}$ & $\begin{array}{l}\mathrm{CO} \\
(\mathrm{ppm})\end{array}$ \\
\hline PPR Taman & $\mathrm{A}$ & 20.95 & 692 & 1.0 \\
Wahyu II & $\mathrm{B}$ & 20.96 & 776 & 3.0 \\
& $\mathrm{C}$ & 20.95 & 583 & 2.0 \\
& Field & 20.95 & 626 & 1.0 \\
PPR Intan & $\mathrm{A}$ & 20.96 & 718 & 2.0 \\
Baiduri & $\mathrm{B}$ & 20.94 & 700 & 2.0 \\
& $\mathrm{C}$ & 20.86 & 642 & 1.0 \\
& Field & 20.96 & 647 & 1.0 \\
\hline
\end{tabular}

Table 3: Biological parameters mean readings about outdoor air quality

\begin{tabular}{lllr}
\hline Location & Zone & Bacteria (cfu) & Fungus (cfu) \\
\hline PPR Taman & A & 11 & 6 \\
Wahyu II & B & 20 & 12 \\
& C & 19 & 6 \\
PPR Intan & Field & 21 & 8 \\
Baiduri & A & 12 & 15 \\
& B & 13 & 3 \\
& C & 9 & 5 \\
& Field & 9 & 1 \\
\hline
\end{tabular}

Table 4: The concentration mean for indoor air quality parameters of research building

\begin{tabular}{llccc}
\hline Location & Parameter & Minimum & Maximum & Mean $\pm \mathrm{SD}$ \\
\hline Wahyu & Temperature $\left({ }^{\circ} \mathrm{C}\right)$ & 27.10 & 29.70 & $28.50 \pm 0.44$ \\
& Relative humidity $(\%)$ & 70.00 & 83.00 & $82.67 \pm 2.08$ \\
& Air velocity $(\mathrm{m} / \mathrm{sec})$ & 0.15 & 0.40 & $0.26 \pm 0.09$ \\
& $\mathrm{H}_{2} \mathrm{~S}$ gas $(\mathrm{ppm})$ & 0.00 & 0.00 & $0.0 \pm 0.00$ \\
$\mathrm{CO}_{2}$ gas $(\mathrm{ppm})$ & 821.00 & 964.00 & $877.83 \pm 59.40$ \\
& $\mathrm{Gas} \mathrm{CO}(\mathrm{ppm})$ & 4.00 & 6.00 & $5.00 \pm 0.89$ \\
& $\mathrm{Gas} \mathrm{O}_{2}(\%)$ & 20.90 & 21.00 & $20.93 \pm 0.05$ \\
$\mathrm{Kadmium}\left(\mathrm{ng} / \mathrm{m}^{3}\right)$ & 0.09 & 0.73 & $0.28 \pm 0.26$ \\
& Plumbum $\left(\mathrm{ng} / \mathrm{m}^{3}\right)$ & 0.28 & 0.83 & $0.45 \pm 0.21$ \\
$\mathrm{TSP}\left(\mathrm{mg} / \mathrm{m}^{3}\right)$ & 0.10 & 0.30 & $0.22 \pm 0.08$ \\
Bakteria $(\mathrm{cfu})$ & 14.00 & 60.00 & $38 \pm 16$ \\
Fungus $(\mathrm{cfu})$ & 3.00 & 22.00 & $11 \pm 7$ \\
\hline
\end{tabular}

Table 5: The $\mathrm{P}$ and $\mathrm{T}$ values from independent $\mathrm{t}$-test

\begin{tabular}{lcc}
\hline Parameters & T value & P value \\
\hline Temperature $\left({ }^{\circ} \mathrm{C}\right)$ & 1.625 & 0.179 \\
Realitive humidity $(\%)$ & -0.376 & 0.740 \\
Air velocity $(\mathrm{m} / \mathrm{sec})$ & 0.928 & 0.083 \\
$\mathrm{CO}_{2}$ gas $(\mathrm{ppm})$ & 4.760 & $0.001^{*}$ \\
$\mathrm{CO}$ gas $(\mathrm{ppm})$ & 0.791 & 0.454 \\
$\mathrm{O}_{2}$ gas $(\%)$ & 2.437 & $0.035^{*}$ \\
$\mathrm{Lead}\left(\mathrm{ng} / \mathrm{m}^{3}\right)$ & -0.178 & 0.862 \\
$\mathrm{Cadmium}\left(\mathrm{ng} / \mathrm{m}^{3}\right)$ & 1.669 & 0.126 \\
TSP $\left(\mathrm{mg} / \mathrm{m}^{3}\right)$ & 2.236 & $0.049^{*}$ \\
Total bacteria count $(\mathrm{cfu})$ & 2.651 & $0.024^{*}$ \\
Total fungal count $(\mathrm{cfu})$ & 2.241 & $0.049^{*}$ \\
\hline
\end{tabular}

*: Significance value of $\mathrm{p}<0.05$ 
Table 5 indicates the $\mathrm{P}$ and $\mathrm{T}$ value from the independence T-test. The Independence T-test was used to compare the concentration mean of indoor air quality in the research with control building.

\section{DISCUSSION}

The study showed that the reading of outdoor air quality for methane was still $0 \mathrm{ppm}$, even though the study location was a former landfill site. This is because methane only being produced when there is no oxygen present at the site (ATSDR, 2001; Kreith and Tchobanoglous, 2002). Besides, methane and hydrogen sulfide productions also depend on a few factors such as type, amount and age of buried waste. These two gases production is higher when the buried wastes are organic origin and in large amount.

In general, newly buried wastes (less than 10 years) will produce higher landfill gases through the bacteria degradation process, chemical reactions and evaporation of buried substances as compared to the old landfill (more than 10 years) (ATSDR, 2001). According to Encyclopedia of Earth (2010), hydrogen sulfide can only maintain in the atmosphere for $18 \mathrm{~h}$. It is then will change into sulfur dioxide and sulfuric acid through chemical reactions with air. Study location was a former landfill site for more than 10 years so it is highly possible that the hydrogen sulfide produced during the phase 2 degradation process has been changed into another form.

Based on the results in biological study for both parameters, mean showed that the total colony count are higher at studied location compared to control location where mean for bacteria at PPR Taman Wahyu II is $17.75 \pm 4.573 \mathrm{cfu}$ and $8.0 \pm 2.828 \mathrm{cfu}$ for PPR Intan Baiduri. The former landfill site which is now became a residential building after went through a redevelopment process, where these urbanization processes can produce aerosols rich with various microorganism populations.

All the parameters for indoor air quality measured fulfilled the Singapore National Environment Agency (NEA) Guidelines 2009 and Single Component EPA Protocol Gas 2003 for landfill gases except temperature, relative humidity, air velocity and total suspended particulates parameters. For temperature parameter, both the research and control building have shown the mean concentration that exceeded the guideline standard. The same goes to the mean concentration for relative humidity parameter which also exceeded the guideline standard. For air velocity and total suspended particulates, the mean concentration has shown that the research building, PPR Taman Wahyu II slightly exceeded the guideline standard, the Singapore National Environment Agency (NEA) Guidelines 2009.
The concentration means of the temperature parameter in the research and control building are $28.50 \pm 0.44^{\circ} \mathrm{C}$ and $28.07 \pm 0.15^{\circ} \mathrm{C}$ respectively which are higher than $22.5-25.5^{\circ} \mathrm{C}$ as proposed by the standard guideline. The concentration means for relative humidity in both buildings are $82.67 \pm 2.08$ and $84.67 \pm 8.96 \%$ which are higher than $\leq 70 \%$ as proposed by the standard. The concentration means of the air velocity parameter in the research building is $0.258 \pm 0.09$ $\mathrm{m} \mathrm{sec}^{-1}$ which is slightly higher than $0.25 \mathrm{~m} \mathrm{sec}^{-1}$ as the standard guideline. The same finding in the concentrated means of total suspended particulates parameter that have been shown $0.217 \pm 0.00 \mathrm{mg} \mathrm{m}^{-3}$ as compared to $0.15 \mathrm{mg} \mathrm{m}^{-3}$ according to the standard guideline.

From Table 5, we can conclude that the concentration mean for carbon dioxide gas, oxygen gas, total suspended particulates, total bacteria and total fungal count showed a significant difference between the research and control building. All these parameters showed that the mean concentration for research building is higher than the control building.

The decomposition phase which occurs at the landfill site is comprised of 4 phases which are phase I, II, III and IV (ATSDR, 2001). Phase I, releasing of carbon dioxide gas, phase II, releasing of carbon dioxide and hydrogen gas and phase III, releasing of acetate, an organic acid. Phase IV is a phase which releases methane gas and this phase normally occurs after 20 years but the release of gases still occurs after 50 years or more. Methane gas comprises of $45-60 \%$ of landfill gases (ATSDR, 2001). The age of the landfill site at PPR Taman Wahyu II is about 15 years and still not reach the phase IV. Therefore the landfill site in this location is still not release the methane gas and if presence, it is just in small quantity.

The independence t-test indicates that there is no significant difference between hydrogen sulfide gas in the research and the control building because after the sampling tasks, the reading for hydrogen sulfide gas is $0 \mathrm{ppm}$ in both buildings. The important factor that leads to this situation is the landfill site of PPR Taman Wahyu II that is still not reach the Phase IV, which means the final phase of decomposition the organic matter. The age of this landfill site is about 15 years. This final stage will release sulfide which is comprised of hydrogen sulfide gas, dimethyl sulfide and mercaptan) (ATSDR, 2001). Hydrogen sulfide is $0-1 \%$ of the landfill gases. The earlier survey which was done showed that the occupants' complaint about the unpleasant odor that was worsening after the rain.

The earlier theory is that the unpleasant odor comes from the hydrogen sulfide gas which released from the landfill site. But after the sampling task was 
over, it reveals that the unpleasant odor comes from the illegal dump site nearby the residential area. Hydrogen sulfide gas is a natural occurring gas and it gives the bad odor to the landfill site (ATSDR, 2001). The reading in control building is $0 \mathrm{ppm}$ because it is not built on the former landfill site.

The concentration mean of total suspended particulates is higher in Taman Wahyu II compared to Intan Baiduri because Taman Wahyu II is located near to the roadside. The dust from the vehicles will move into and trapped inside the houses. Its concentration depends on the relative humidity, speed and direction of air and also rain (Komarnicki, 2004).

The total fungal count was higher in Taman Wahyu II because it is located on the former landfill site. The total fungal count on the former landfill site are 5-20 times higher than the surrounding area. This situation shows that the indoor air quality in the building built on the former landfill site is not good since the exposure to particle carrying fungal is the best parameter to access indoor air quality (Rahkonen et al., 1990).

As for the comparison, all the landfill gases measured were compared to the standard in EPA Protocol Gas for Single Component. The results of the comparison showed that all the Landfill Gases (LFG) concentration measured are not exceed the standards.

\section{CONCLUSION}

Statistical analysis found that there are 3 parameters with significant difference but if it was compared with mean, there was only very small or slightly different in these 3 parameter readings. For other parameters, there is no significant difference. For the chemical parameters, all of the landfill gas concentrations are not exceeding the EPA Protocol Gas for Single Component. Overall, the research has shown that there are no different between air quality of the building built on a former landfill site and the control building. PPR Taman Wahyu II is safe to be occupied for most of the parameters of the air quality measured are still below the standards.

\section{REFERENCES}

Samsudin, A.R., B.E.E.A. Rahim, W.Z.W. Yaacob and U. Hamzah, 2006. Mapping of contamination plumes at municipal solid waste disposal sites using the geoelectric imaging technique: Case studies in Malaysia. J. Spatial Hydrol., 6: 52-62.

ATSDR, 2001. Agency For Toxic Substances and Disease Registry. Landfill Gas Primer. An Overview for Environmental Health Professionals.

Fierro, M., 2000. Particulate Matter. 1st Edn., pp: 11.

Jarup, L., 2003. Hazards of heavy metal contamination. Br. Med. Bull., 68: 167-182. DOI: 10.1093/bmb/ldg032

Komarnicki, G.J.K., 2004. Lead and cadmium in indoor air and the urban environment. Environ. Pollut., 136: 47-61. DOI: 10.1016/j.envpol.2004.12.006

Kreith, F. and G. Tchobanoglous, 2002. Handbook of Solid Waste Management. 2nd Edn., McGraw Hill, New York, ISBN-10: 0071356231, pp: 950.

NIOSH, 2003. National Institute of Occupational Safety and Health. NIOSH.

Rahkonen, P., M. Ettala, M. Laukkanen and M. Salkinoja-Salonen, 1990. Airborne microbes and endotoxins in the work environment of two sanitary landfills in Finland. Aerosol Science Technology, 13: 505-513. DOI: 10.1080/02786829008959465

Schrapp, K. and N. Al-Mutairi, 2010. Associated health effects among residences near jeleeb al-shuyoukh landfill. Am. J. Environ. Sci., 6: 184-190. DOI: 10.3844/ajessp. 2010.184.190 